\title{
THE DIFFERENTIATION OF SHEEP BREED BASED ON THE BODY MEASUREMENTS
}

\author{
E. Handiwirawan 1 , R. R. Noor ${ }^{2}$, C. Sumantri ${ }^{2}$ and Subandriyo ${ }^{3}$ \\ ${ }^{1}$ Indonesian Center for Animal Research and Development, \\ Jl. Raya Pajajaran Kav E-59, Bogor 16151 - Indonesia \\ ${ }^{2}$ Faculty of Animal Science, Bogor Agriculture University, \\ Jl. Agatis, Darmaga Campus, Bogor - Indonesia \\ ${ }^{3}$ Indonesian Research Institute for Animal Production, \\ Jl. Banjarwaru, PO Box 221, Ciawi-Bogor 16002 - Indonesia \\ Correspondinge-mail: eh_wirawan@yahoo.com
}

Received January 10, 2011; Accepted February 21, 2011

\begin{abstract}
This research was carried out to make a difference and to predict genetic distance some sheep that are genetically related to each other based on the body size measurements. Nineteen bodies size of 323 sheeps of five sheep breeds; namely Barbados Black Belly Cross (BC), Garut Local (GL), Garut Composite (GC), Sumatra Composite (SC) and St. Croix Cross (SCC) were measured. Analysis of variance and canonical discriminant analysis, Mahalanobis distance, plotting canonical and dendogram were performed using PROC GLM, PROC CANDISC, PROC CLUSTER and PROC TREE of SAS software ver. 9.0. Index Length, Width Slope, Depth Slope, Balance and Cumulative Index of GC sheep were significantly higher than the four other breeds. Canonical discriminant analysis successfully could differentiate among the five sheep breeds. All five breed were divided into two groups: the first group consisted of SCC, SC and BC; and the second group consisted of the GL and GC. The results of genetic distance estimation showed that the SCC had a value of sheep genetic distance closest to SC (10.83) and BC (27.98), while GL had the closest distance to GC (66.60). The tail width, horn base circumference, horn length (canonical 1) and variable length of the tail and body length (canonical 2) were the breed differentiation variable in this study.
\end{abstract}

Keywords: body size, differentiation of breed, genetically related, sheep

\section{INTRODUCTION}

Many researchers gave an attention to the body size of livestock animal as the object being observed. Several studies reported a strong correlation between some linear body sizes with some production traits, i.e. linear body size can be used to estimate the body weight of sheep (Otoikhian et al., 2008; Abdel-Moneim, 2009) and goats (Mukherjee et al., 1981, 1986; Singh et al., 1987; Adeyinka and Muhammad, 2006; Jimmy et al., 2010). Also, it can be used to estimate some properties of lamb carcass trait (Abdel-Moneim et al., 2009), or to estimate the litter size in goat (Marai et al., 2006).

Multivariate analysis of some linear body size was used by Traore et al. (2008) to differentiate among breed and to calculate genetic distance Mahalanobis goat in Burkina Faso. Body size has also been used to differentiate the Indonesia local sheep (Suparyanto et al., 1999;
Mansjoer et al., 2007), goat (Lanari et al., 2003), and duck (Brahmantiyo, 2003). Another technique that can be used to estimate the diversity and genetic distance is blood protein polymorphisms (Shahrbabak et al., 2010). Microsatellite DNA markers have been used to describe the goat genetic diversity and distance (Mahmoudi et al., 2010; Li et al., 2002.), and the sheep breed (Tapio et al., 2010; Kusza et al., 2010). Mitochondrial DNA sequence has been reported to calculate of the genetic distance in sheep (Wu et al., 2003). However, work related to proteins and DNA requires relatively good laboratory equipments, so the cost is relatively expensive and adequate mastery of technique. Data collection of body size is relatively easier to get and inexpensive when compared to protein or DNA data collection.

Garut Composite (GC), Sumatra Composite (SC), Barbados Black Belly Cross (BC) and St. Croix Cross (SCC) are some of the synthetic 
sheep breed from breeding research in the long term, established by the Indonesian Research Institute for Animal Production. Generally, the selection in those breed is always done based on economically important production traits. The GC sheep inherited genetic contributions from Moulton Charollais, St. Croix and GL sheep. Meanwhile, SC sheep is a crossbred between Barbados Black Belly, St. Croix and Sumatra Local sheep. The existence of a genetic relationship among some of those sheep breed resulted in some similarities and differences among of those breed. If the similarity is very high, then technique to differentiate will become increasingly difficult. Previous researches have used the body size data to differentiate among sheep breeds that were genetically unrelated. Thus, this study was aimed to differentiate and estimate the genetic distance of among the sheep breed that are genetically related based on body measurements data.

\section{MATERIALS AND METHODS}

Sheep used were five sheep breeds, namely Barbados Black Belly Cross sheep (a crossbred between Barbados Black Belly and Sumatra Local sheep, 50\% Barbados Black Belly 50\% Sumatra Local), Garut Local sheep, Garut Composite sheep (25\% Moulton Charollais 25\% St. Croix $50 \%$ Garut Local sheep) and Sumatra Composite sheep (25\% Barbados Black Belly 25\% St. Croix $50 \%$ Sumatra Local sheep), St. Croix Cross sheep (50\% St. Croix 50\% Sumatra Local sheep). Data were collected from five sheep breeds that were kept in the Cilebut and Bogor Animal House as many as 323 animals, which more than 1 years old. The breed consists of 54 heads BC sheep (15 males 39 females), 36 heads GL sheep (8 males 28 females), 55 heads GC sheep (18 males 37 females), 95 heads SC sheep (25 males 70 females) and 83 heads SCC sheep (17 males 66 females). Measurements were not conducted in the pregnant sheep to eliminate the influence of several body sizes.

Phenotype characterization of every sheep breed was observed following the method of Handiwirawan et al. (2007). Nineteen quantitative characteristics observed from several parts of the body of the sheep were body weight (BW), skull length (SKLLGT), skull width (SKLWDT), skull height (SKLHGT), horn length (HRNLGT), horn base circumference (HRNBCIR), ear length (EARLGT), ear width (EARWDT), wither height
(WTRHGT), body length (BDLGT), chest width (CSTWDT), chest girth (CSTGRT), chest depth (CSTDPT), right cannon circumference (CNCIR), hip height (HIPHGT), hip width (HIPWDT), rump length (RMPLGT), tail length (TLLGT), tail width (TLWDT).

Prior to the discriminant analysis was performed, body size data were corrected based on sex and age. PROC GLM SAS software ver. 9.0 (SAS, 2002) was used to obtain the value of correction factor for the sex and age. The least squares means (LSM) ranges from the above analysis was used to determine the sheep's body size correction factor by sex and age. Correction factor for sex and age were calculated by adding or subtracting LSM data. Data were corrected for ram and age group above 3 years.

PROC GLM SAS software ver. 9.0 (SAS, 2002) was used for analysis of variance of quantitative traits and significance test was conducted to compare quantitative traits between sheep breed. Linear model used was:

where:

$$
Y_{i j}=\mu+B_{i}+\varepsilon_{i j}
$$

$\begin{aligned} \mathrm{Y}_{\mathrm{ij}} & =\text { Body size } \\ \mu & =\text { Population mean } \\ \mathrm{B}_{\mathrm{i}} & =\text { Effect of } \mathrm{i}^{\text {th }} \text { sheep breed }(\mathrm{i}=1, \ldots, 5) \\ \varepsilon_{\mathrm{ij}} & =\text { Random effect }\end{aligned}$

CANDISC PROC SAS software ver. 9.0 (SAS, 2002) was used to perform canonical discriminant analysis to calculate the Mahalanobis distance, canonical coefficient and give a visual interpretation of the differences in sheep. Based on the Mahalanobis distance matrix that was generated from the previous analysis, PROC CLUSTER with Average Linkage Method (Unweighted Pair-Group Method Using Arithmetic Averages, UPGMA) performed a hierarchical clustering, and then the dendogram for the five sheep breeds was created using PROC TREE from SAS software ver. 9.0 (Herrera et al., 1996; SAS, 2002).

Morphology index was calculated based on Salako (2006) and Alderson (1999) methods, in order to assess the type and function of the five of sheep breed. Morphology index was calculated as follows:

1. Height slope (HGTSLP) = wither height rump height

2. Length index (LGTIDX) = body length / wither height

3. Width slope (WDTSLP) $=$ hip width / chest width 
4. Depth index $($ DPTIDX $)=$ chest depth $/$ wither height

5. Foreleg length (FRLLGT) $=$ wither height chest depth

6. Balance $($ BALC) $=$ (rump length $\mathrm{x}$ hip width) / (chest depth $\mathrm{x}$ chest width)

7. Cumulative index (CUMIDX) $=$ (weight $/$ breed average weight) + length index + balance

PROC GLM SAS software ver. 9.0 (SAS, 2002) was used for conducting the analysis of variance of the observed index value and significance test was conducted to compare each index value between sheep breed. Linear model used was:

$$
\mathrm{Y}_{\mathrm{ij}}=\mu+\mathrm{B}_{\mathrm{i}}+\varepsilon_{\mathrm{ij}}
$$

where:

$\begin{aligned} \mathrm{Y}_{\mathrm{ij}} & =\text { Index value } \\ \mu & =\text { Population mean } \\ \mathrm{B}_{\mathrm{i}} & =\text { Effect of } \mathrm{i}^{\text {th }} \text { sheep breed }(\mathrm{i}=1, \ldots . ., 5) \\ \varepsilon_{\mathrm{ij}} & =\text { Random effect }\end{aligned}$

\section{RESULTS AND DISCUSSION}

Nineteen variables body size from the five breeds of sheep and tests of significance among the five breeds of the sheep is presented in Table 1. Based on the BW and many other body sizes, GL was the smallest sheep. GL had the largest sizes for HRNLGT, HRNBCIR and CSTWDT. HRNLGT and HRNBCIR of GL sheep reached 34.6 and $20.4 \mathrm{~cm}$ respectively. SCC sheep was the heaviest and the highest (WTRHGT and HIPHGT). Besides that the SCC sheep had the largest of SKLLGT, SKLWDT, CSTGRT, CNCIR and RMPLGT. GC sheep had the longest of all sheep for skull size (SKLLGT, SKLWDT, and SKLHGT), body length (BDLGT), chest size (CSTWDT and CSTGRT), hip size (LGPG) and the size of the tail (TLLGT and TLWDT). SC sheep had the longest body size for skull size (SKLLGT and SKLWDT), ear size (EARLGT and EARWDT), and chest size (CSTWDT and CSTDPT). For all the variables body size, BC sheep did not have the smallest variable. BC sheep had moderate body size when compared to the other breed, and had the longest three variables, namely EARLGT and CSTDPT (with $\mathrm{SC}$ ), and BDLGT (with GC).

Alderson (1999) and Salako (2006) reported the use of the body size index in cattle and sheep to assess the type and function of breeds of livestock. Following the index formula of Alderson (1999) and Salako (2006), the value of the index between 5 breeds of sheep is presented in Table 2.

Sheep's wither was higher than rump (Salako, 2006), as well as the sheep breeds observed in this research. However, the difference between the heights (wither and rump) was not the same in the five breeds. BC had the highest HGTSLP index, while the lowest was GL, GC and SC sheep. Based on the index, from the side $\mathrm{BC}$ will look sloping backward from posterior while GL, GC and SC look relatively flat.

The GC sheep had the highest value of LGTIDX, WDTSLP and DPTIDX, in which was very different from four other breeds. LGTIDX value of GC sheep was almost 1.5 , while the other four sheep had values ranging from 0.84 to 1.09 . Meanwhile, value of INDLM and WDTSLP of GC sheep were 1.20 (vs. 0.88 to 1.07 ) and 0.66 (vs. 0.42 to 0.52 ). Thus, GC sheep looked longer, wider at the rump and higher at CSTDPT proportion in WTRHGT while the other sheep are relatively balanced between the BDLGT and WTRHGT, balanced between RMPWDT and CSTWDT and the proportion in the chest was lower. The three index values above showed that $\mathrm{GC}$ was a meat type, similar to the one of their parents i.e. Moulton Charollais sheep which is a meat type sheep and better than the other four sheep.

The value of FRLLGT of SCC sheep was the highest while the lowest was GC sheep. The FRLLGT of SCC sheep approximately $56.8 \%$ of WTRHGT, while the value in GC sheep was only about $34.2 \%$ of WTRHGT. Based on the index value of BALC, GC sheep had the highest index value, while the lowest was in the GL sheep (0.91 vs. 0.64).

The CUMIDX is a useful indicator of the overall value because it combines morphology and structure and provide an accurate picture of the type of breed. This value is relatively fixed during the lives of animals and can be used in young animals to estimate the adults merit (Alderson, 1999). The highest CUMIDX was found at GC and the lowest was GL and SCC sheep (3.38 vs. 2.62 and 2.61).

The CUMIDX has the potential to be applied in the study of types and functions in the livestock breeds. However, according to Alderson (1999), the CUMIDX is considered less attractive because the calculation requires five linear body sizes. In 
Table 1. Least Squares Means of Body Size of Barbados Black Belly Cross (BC), Garut Local (GL), Garut Composite (GC), Sumatra Composite (SC) and St. Croix Cross (SCC) Sheep

\begin{tabular}{|c|c|c|c|c|c|}
\hline \multirow{2}{*}{ Body Measurement } & \multicolumn{5}{|c|}{ Breed of Sheep } \\
\hline & $\mathrm{BC}$ & GL & $\mathrm{GC}$ & $\mathrm{SC}$ & SCC \\
\hline BW (kg) & $41.60 \pm 0.60^{\mathrm{a}}$ & $36.80 \pm 0.73^{b}$ & $44.61 \pm 0.59^{\mathrm{c}}$ & $43.00 \pm 0.45^{\mathrm{a}}$ & $46.21 \pm 0.48^{d}$ \\
\hline SKLLGT (cm) & $22.56 \pm 0.21^{\mathrm{a}}$ & $21.91 \pm 0.25^{\mathrm{b}}$ & $23.90 \pm 0.20^{\mathrm{c}}$ & $23.88 \pm 0.16^{\mathrm{c}}$ & $23.72 \pm 0.17^{\mathrm{c}}$ \\
\hline SKLWDT (cm) & $14.93 \pm 0.14^{\mathrm{a}}$ & $13.32 \pm 0.17^{\mathrm{b}}$ & $15.53 \pm 0.14^{\mathrm{c}}$ & $15.40 \pm 0.11^{\mathrm{c}}$ & $15.42 \pm 0.11^{\mathrm{c}}$ \\
\hline SKLHGT (cm) & $16.38 \pm 0.15^{\mathrm{a}}$ & $15.51 \pm 0.18^{b}$ & $17.76 \pm 0.15^{\mathrm{c}}$ & $15.93 \pm 0.11^{\mathrm{ab}}$ & $16.19 \pm 0.12^{\mathrm{a}}$ \\
\hline HRNLGT (cm) & $5.17 \pm 0.70^{\mathrm{a}}$ & $34.58 \pm 0.86^{\mathrm{b}}$ & $14.99 \pm 0.70^{\mathrm{c}}$ & $0.04 \pm 0.53^{\mathrm{d}}$ & $0.02 \pm 0.57^{\mathrm{d}}$ \\
\hline HRNBCIR (cm) & $4.20 \pm 0.40^{\mathrm{a}}$ & $20.42 \pm 0.49^{b}$ & $9.33 \pm 0.39^{c}$ & $0.63 \pm 0.30^{\mathrm{d}}$ & $0.001 \pm 0.32^{\mathrm{d}}$ \\
\hline EARLGT (cm) & $11.04 \pm 0.29^{\mathrm{ac}}$ & $7.10 \pm 0.36^{\mathrm{b}}$ & $10.76 \pm 0.29^{\mathrm{a}}$ & $11.66 \pm 0.22^{\mathrm{c}}$ & $9.36 \pm 0.24^{\mathrm{d}}$ \\
\hline EARWDT (cm) & $5.99 \pm 0.15^{\mathrm{a}}$ & $4.46 \pm 0.18^{b}$ & $5.38 \pm 0.14^{\mathrm{c}}$ & $6.57 \pm 0.11^{\mathrm{d}}$ & $6.18 \pm 0.12^{\mathrm{a}}$ \\
\hline WTRHGT (cm) & $62.29 \pm 0.57^{\mathrm{a}}$ & $58.79 \pm 0.70^{\mathrm{b}}$ & $46.26 \pm 0.56^{\mathrm{c}}$ & $68.79 \pm 0.43^{d}$ & $73.08 \pm 0.46^{\mathrm{e}}$ \\
\hline BDLGT (cm) & $66.93 \pm 0.49^{\mathrm{a}}$ & $58.19 \pm 0.60^{\mathrm{b}}$ & $68.00 \pm 0.48^{\mathrm{a}}$ & $65.19 \pm 0.37^{\mathrm{c}}$ & $61.27 \pm 0.39^{d}$ \\
\hline CSTWDT (cm) & $18.89 \pm 0.30^{\mathrm{a}}$ & $20.38 \pm 0.37^{b}$ & $20.19 \pm 0.30^{b}$ & $19.86 \pm 0.23^{b}$ & $17.38 \pm 0.25^{\mathrm{c}}$ \\
\hline CSTGRT $(\mathrm{cm})$ & $83.77 \pm 0.70^{\mathrm{a}}$ & $77.15 \pm 0.86^{\mathrm{b}}$ & $88.49 \pm 0.69^{c}$ & $85.30 \pm 0.53^{\mathrm{a}}$ & $88.36 \pm 0.56^{\mathrm{c}}$ \\
\hline CSTDPT (cm) & $31.75 \pm 0.30^{\mathrm{ab}}$ & $28.26 \pm 0.37^{\mathrm{c}}$ & $30.44 \pm 0.30^{\mathrm{d}}$ & $32.30 \pm 0.23^{\mathrm{a}}$ & $31.55 \pm 0.25^{b}$ \\
\hline CNCIR (cm) & $6.96 \pm 0.09^{\mathrm{a}}$ & $6.78 \pm 0.12^{\mathrm{a}}$ & $7.30 \pm 0.09^{b}$ & $8.14 \pm 0.07^{\mathrm{c}}$ & $8.72 \pm 0.07^{\mathrm{d}}$ \\
\hline HIPHGT (cm) & $57.78 \pm 0.54^{\mathrm{a}}$ & $59.83 \pm 0.66^{\mathrm{b}}$ & $46.38 \pm 0.54^{\mathrm{c}}$ & $68.47 \pm 0.41^{\mathrm{d}}$ & $70.56 \pm 0.44^{\mathrm{e}}$ \\
\hline HIPWDT (cm) & $19.58 \pm 0.37^{\mathrm{a}}$ & $17.99 \pm 0.45^{\mathrm{b}}$ & $23.97 \pm 0.36^{\mathrm{c}}$ & $21.12 \pm 0.28^{d}$ & $16.91 \pm 0.30^{\mathrm{e}}$ \\
\hline RMPLGT (cm) & $22.66 \pm 0.26^{\mathrm{a}}$ & $20.08 \pm 0.32^{b}$ & $22.56 \pm 0.26^{\mathrm{a}}$ & $22.89 \pm 0.20^{\mathrm{a}}$ & $25.10 \pm 0.21^{\mathrm{c}}$ \\
\hline TLLGT $(\mathrm{cm})$ & $23.85 \pm 0.40^{\mathrm{a}}$ & $18.58 \pm 0.49^{b}$ & $29.65 \pm 0.39^{c}$ & $23.36 \pm 0.30^{\mathrm{a}}$ & $25.95 \pm 0.32^{d}$ \\
\hline TLWDT (cm) & $5.27 \pm 0.13^{\mathrm{a}}$ & $6.62 \pm 0.5^{b}$ & $7.29 \pm 0.13^{\mathrm{c}}$ & $4.77 \pm 0.10^{\mathrm{a}}$ & $4.41 \pm 0.12^{\mathrm{e}}$ \\
\hline
\end{tabular}

Different superscript on the same row indicates significant different $(\mathrm{P}<0.05)$

BW = body weight, SKLLGT = skull length, SKLWDT = skull width, SKLHGT = skull height, HRNLGT = horn length, HRNBCIR = horn base circumference, EARLGT $=$ ear length, EARWDT $=$ ear width, WTRHGT $=$ wither height, BDLGT = body length, CSTWDT = chest width, CSTGRT = chest girth, CSTDPT $=$ chest depth, CNCIR $=$ right cannon circumference, HIPHGT $=$ hip height, HIPWDT $=$ hip width, RMPLGT = rump length, TLLGT = tail length, TLWDT $=$ tail width

practice may be HIPWDT and RMPLGT are the preferred measurements because it has a high correlation with CUMIDX and BW. Dario et al. (2008) reported that the value of heritability of WTRHGT, CSTGRT and CNCIR of donkey in the range from medium to high. Utilization of traits that has a moderate to high heritability as the basis of mass selection will be able to provide a high selection progress.

The total canonical structure analysis of body size variables resulted in several body size variables that provide a strong influence on a typical breed of sheep. TLWDT (0.771419), HRNBCIR (0.765007), HRNLGT (0.744169) (based on the structure of canonical 1) and TLLGT (0.660410), BDLGT (0.643200) (based on the structure of canonical 2) were the body size measurement that have a relatively high value and variables of differentiator for the sheep breed. Types of differentiator variables obtained in the study may differ depending on the sheep used in research. Mansjoer et al. (2007) found that the length of the ear and ear width (canonical 1) and width of the tail and chest width (canonical 2) as a 
Table 2. Index Value of Body Size of Barbados Black Belly Cross (BC), Garut Local (GL), Garut Composite (GC), Sumatra Composite (SC) And St. Croix Cross (SCC) Sheep

\begin{tabular}{lccccc}
\hline $\begin{array}{l}\text { Index of Body } \\
\text { Weight }\end{array}$ & \multicolumn{5}{c}{ Breed of Sheep } \\
\cline { 2 - 6 } & BC & GL & GC & SC & SCC \\
\hline HGTSLP & $4.33 \pm 0.33^{\mathrm{a}}$ & $1.04 \pm 0.41^{\mathrm{b}}$ & $0.12 \pm 0.33^{\mathrm{bc}}$ & $0.32 \pm 0.25^{\mathrm{c}}$ & $2.52 \pm 0.27^{\mathrm{d}}$ \\
LGTIDX & $1.09 \pm 0.02^{\mathrm{a}}$ & $0.99 \pm 0.02^{\mathrm{b}}$ & $1.49 \pm 0.02^{\mathrm{c}}$ & $0.95 \pm 0.01^{\mathrm{d}}$ & $0.84 \pm 0.01^{\mathrm{e}}$ \\
WDTSLP & $1.04 \pm 0.02^{\mathrm{a}}$ & $0.88 \pm 0.02^{\mathrm{b}}$ & $1.20 \pm 0.02^{\mathrm{c}}$ & $1.07 \pm 0.01^{\mathrm{a}}$ & $0.98 \pm 0.01^{\mathrm{d}}$ \\
DPTIDX & $0.52 \pm 0.009^{\mathrm{a}}$ & $0.49 \pm 0.010^{\mathrm{b}}$ & $0.66 \pm 0.008^{\mathrm{c}}$ & $0.46 \pm 0.006^{\mathrm{b}}$ & $0.42 \pm 0.007^{\mathrm{d}}$ \\
FRLLGT & $30.54 \pm 0.60^{\mathrm{a}}$ & $30.53 \pm 0.73^{\mathrm{a}}$ & $15.83 \pm 0.59^{\mathrm{b}}$ & $36.49 \pm 0.45^{\mathrm{c}}$ & $41.54 \pm 0.48^{\mathrm{d}}$ \\
BALC & $0.74 \pm 0.02^{\mathrm{a}}$ & $0.64 \pm 0.02^{\mathrm{b}}$ & $0.91 \pm 0.02^{\mathrm{c}}$ & $0.75 \pm 0.01^{\mathrm{a}}$ & $0.77 \pm 0.01^{\mathrm{a}}$ \\
CUMIDX & $2.80 \pm 0.03^{\mathrm{a}}$ & $2.62 \pm 0.04^{\mathrm{b}}$ & $3.38 \pm 0.03^{\mathrm{c}}$ & $2.71 \pm 0.02^{\mathrm{d}}$ & $2.61 \pm 0.02^{\mathrm{b}}$ \\
\hline
\end{tabular}

Different superscript on the same row indicates significant different $(\mathrm{p}<0.05)$

HGTSLP $=$ height slope, LGTIDX = length index, WDTSLP $=$ width slope, DPTIDX $=$ depth index, FRLLGT $=$ foreleg length, BALC = balance, CUMIDX = cumulative index

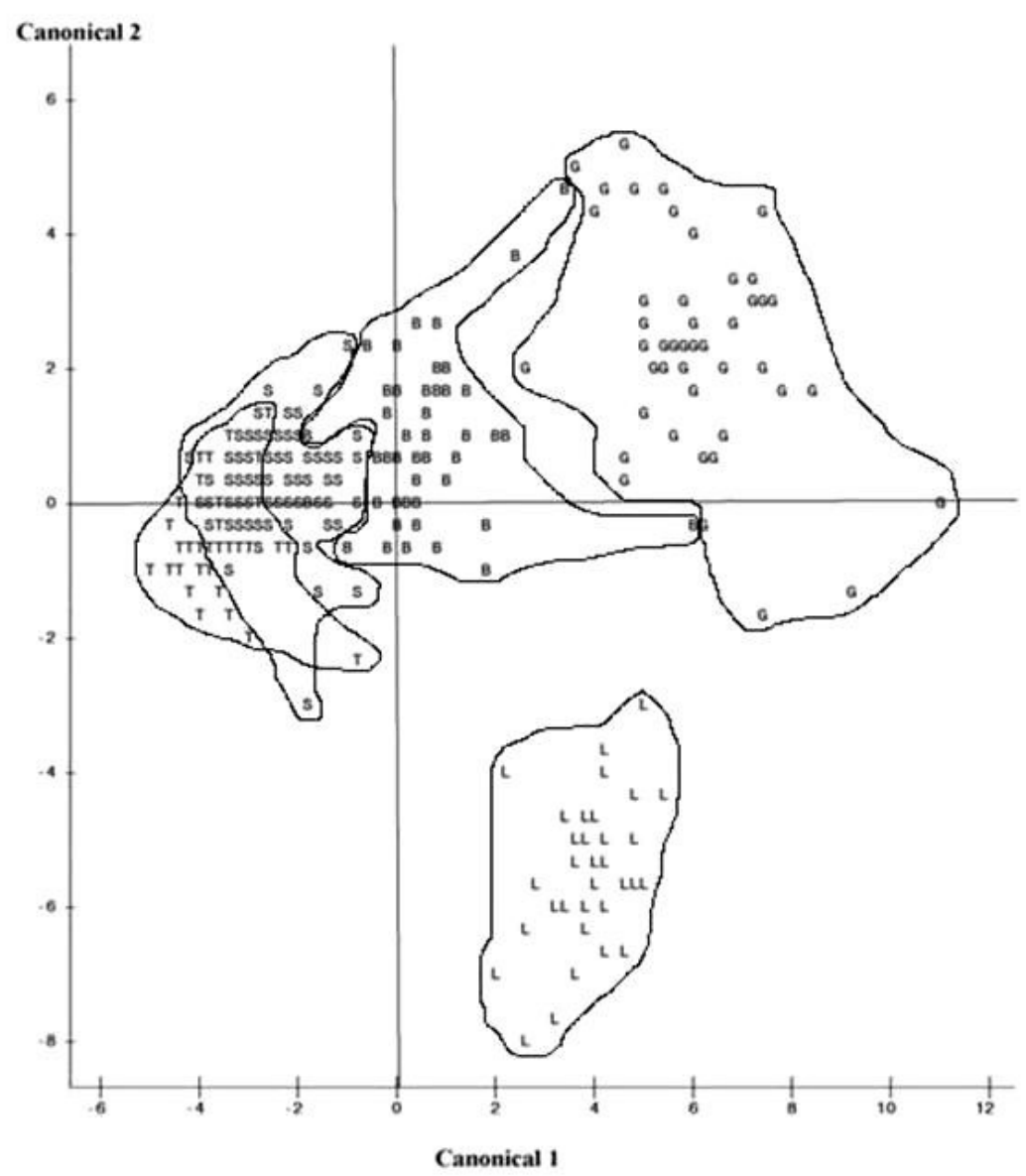

Figure 1. Canonical Plotting that Describes Sheep Breed Grouping Based on Body Size (Symbol of $\mathrm{B}=\mathrm{BC}, \mathrm{L}=\mathrm{GL}, \mathrm{G}=\mathrm{GC}, \mathrm{S}=\mathrm{SC}, \mathrm{T}=\mathrm{SCC}$ ) 
differentiator variable for Garut meat and fighting sheep types. Similarly, Gunawan and Sumantri (2008) found tail width, shoulder height and body length (canonical 1) and chest width (canonical 2) as a differentiator variable Garut and sheep crosses.

Five sheep breeds grouping based on discriminant canonical analysis depicted as shown in Figure 1. It appears that the five breeds of sheep can be differentiated, although it appears that group of SCC sheep coincide with SC sheep and group of $\mathrm{SC}$ sheep coincide with $\mathrm{BC}$ sheep. Meanwhile, GL and GC sheep clearly separated by SCC, SC and BC sheep. Based on the canonical 1, SCC and SC sheep can be clearly differentiated both by the breed of $\mathrm{BC}$, GL and GC sheep.

Sub-population can be formed due to limited gene flow and geographical isolation so that the sub-populations have different phenotypic characteristics. By using discriminant canonical analysis, Gunawan and Sumantri (2008) could differentiate some sub-populations of West Java local sheep. However, by using the same analysis Salamena et al. (2007) showed that the Kisar sheep in Maluku had not yet established a new sub-population. Similar results were also shown for Central Java local buffalo (Johari et al., 2009) and Maluku local buffalo (Salamena and Papilaja, 2010), several sub-populations were observed could not be differentiated and therefore had not formed a new sub-population.

Mahalanobis distance values between the five sheep breeds are shown in Table 3 and depicted in the dendogram as shown in Figure 2. Figure 2 shows that five sheep breed separated into two major groups, namely the first group consisted of BC, SC, SCC sheeps and the second group consisted of GL and GC sheeps. In the first group, genetic distance of SCC sheep closer to the

Table 3. Mahalanobis Distance Value and Probability of Significance between Five Sheep Breeds

\begin{tabular}{crrrrr}
\hline Breed of Sheep & \multicolumn{1}{c}{ BC } & \multicolumn{1}{c}{ GC } & GL & SC & SCC \\
\hline BC & 0 & 41.0176 & 57.6791 & 17.6186 & 27.9805 \\
GC & $<0.0001$ & 0 & 66.60120 & 77.70561 & 91.39412 \\
GL & $<0.0001$ & $<0.0001$ & 0 & 74.96393 & 81.06285 \\
SC & $<0.0001$ & $<0.0001$ & $<0.0001$ & 0 & 10.83016 \\
SCC & $<0.0001$ & $<0.0001$ & $<0.0001$ & $<0.0001$ & 0 \\
\hline
\end{tabular}

Value on above of the diagonal shows the value of Mahalanobis distance

Values on the below of the diagonal shows the probability of significance of Mahalanobis distance

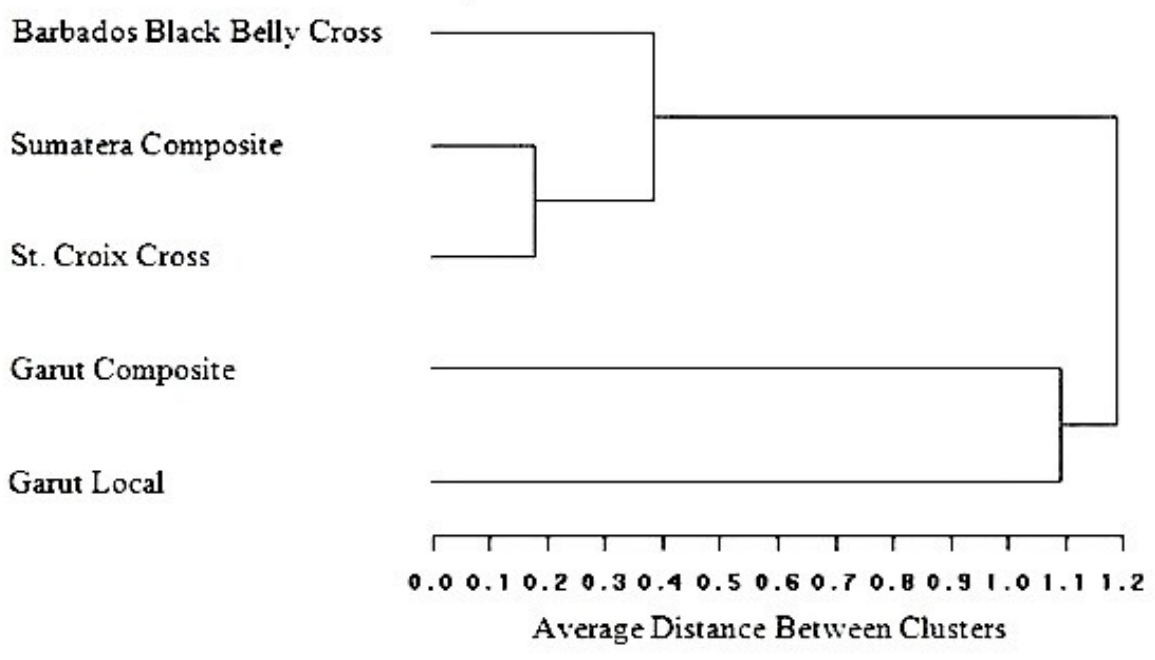

Figure 2. Dendogram Based on the Mahalanobis Distance of the Barbados Black Belly Cross (BC), Garut Local (GL), Garut Composite (GC), Sumatra Composite (SC) and St. Croix Cross (SCC) Sheep 
SC sheep when compared to BC sheep. The result of this analysis is consistent with the formation of SC sheep and GC sheep. SC current sheep populations derived from crosses between $\mathrm{BC}$, SCC and Sumatra Local sheep, so it seems that the three sheeps (BC, SCC and SC) become separate groups. Meanwhile, the GC sheep formed from crosses between Moulton Charollais, St. Croix Cross and GL sheep also formed a second group (GC and GL). The SCC was the ancestor of SC and GC, and Sumatra into a distinct population. The SCC sheep ancestor of $\mathrm{SC}$ sheep was derived from a cross between St. Croix with Local Sumatra sheep, while the SCC sheep ancestor of GC sheep was a cross between St. Croix with Garut local sheep.

\section{CONCLUSION}

Discriminant canonical analysis based on data from nineteen body measurements could differentiate among the sheep of Barbados Black Belly Cross, Garut Local, Garut Composite, Sumatra Composite and St. Croix Cross sheep. Based on the Mahalanobis distance calculation, five sheep were divided into two groups: the first group consists of St. Croix Cross, Sumatra Composite and Barbados Black Belly Cross sheep and the second group consists of Garut local and Garut Composite. SCC sheep had a value of sheep genetic distance closest to SC (10.83) and BC (27.98), while GL had the closest distance to GC (66.60). The variable of tail width, horn base circumference, horn length (canonical 1) and variable of tail length and body length (canonical 2) are a differentiator variable of sheep breeds.

\section{REFERENCES}

Abdel-Moneim, A. Y. 2009. Use of live body measurements for prediction of body and carcass cuts weights in three Egyptian breeds of sheep. Egyptian J. Sheep and Goat Sci. $2: 17-32$.

Adeyinka, I.A. and I.D. Mohammed. 2006. Relationship of live weight and Linear body Measurement in two Breeds of Goat of Northern Nigeria. J. Anim. Vet. Adv. 11: 891-893.

Alderson, G.L.H. 1999. The development of a system of linear measurements to provide an assessment of type and function of beef cattle. AGRI 25:45-55.
Brahmantiyo, B., L.H. Prasetyo, A.R. Setioko and R.H. Mulyono. 2003. Pendugaan jarak genetic dan faktor peubah pembeda galur itik (Alabio, Bali, Khaki Campbell, Mojosari dan Pegagan). JITV 1:1-7.

Dario, C., D. Carnicella, M. Selvaggi, G. Bufano, M. Dario, V. Tufarelli, G.V. Celano and V. Laudadio. 2008. Heritability Estimates for some Biometric Traits in Martina Franca Donkey Breed. Proc. Aust. Soc. Anim. Prod. Vol. 27.

Gunawan, A. and C. Sumantri. 2008. Pendugaan nilai campuran fenotipik dan jarak genetik domba Garut dan persilangannya. J. Indonesian Trop. Anim. Agric. 3:176-185.

Handiwirawan E., S.A. Asmarasari and B. Setiadi. 2007. Panduan Karakteristik Ternak Kambing dan Domba. Pusat Penelitian dan Pengembangan Peternakan. Bogor.

Herrera M, E. Rodero, M.J. Gutierrez, F. Pefia and J.M. Rodero. 1996. Application of multifactorial discriminant analysis in the morphostructural differentiation of Andalusian caprine breeds. Small Rum. Res. 22:39-47.

Jimmy, S., M. David, K. R. Donald and M. Dennis. 2010. Variability in Body Morphometric Measurements and Their Application in Predicting Live Body Weight of Mubende and Small East African Goat Breeds in Uganda. Middle-East J. Scientific Res. 2 : 98-105.

Johari, S., E. Kurnianto, Sutopo and W. A. Hamayanti. 2009. Multivariate analysis of phenotypic traits of body measurement in swamp buffalo (Bubalus bubalis). J. Indonesian Trop. Anim. Agric. 2:289 - 294.

Kusza, S., D. Dimov, I. Nagy, Z. Bõsze, A. Jávorand and S. Kukovics. 2010. Microsatellite analysis to estimate genetic relationships among five bulgarian sheep breeds. Gen. and Molec. Biol. 1:51-56.

Lanari, M. R., T. Héctor, D. Ernesto, P. C. Marcelo and L. Gallo. 2003. Phenotypic differentiation of exterior traits in local Criollo Goat Population in Patagonia (Argentina). Arch. Tires., Dummerstorf 4:347-356.

Li M.H., S. H. Zhao, C. Bian, H.S. Wang, H. Wei, B. Liu, M. Yu, B. Fan, S.L. Chen, M.J. Zhu, S.J. Li, T.A. Xiong and K. Li. 2002. Genetic relationships among twelve chinese indigenous goat populations based on 
microsatellite analysis. Genet. Sel. Evol. 34:729-744.

Mahmoudi, B., M. Bayat, R. Sadeghi, M. Sh. Babayev and H. Abdollahi. 2010. Genetic diversity among three goat populations assessed by Microsatellite DNA markers in Iran. Global Veterinaria $2: 118-124$.

Mansjoer, S.S., T. Kertanugraha and C. Sumantri. 2007. Estimasi jarak genetik antar domba Garut tipe tangkas dengan tipe pedaging. Media Peternakan 2:129-138.

Marai, I.F.M., A.A. El-Darawany, K.M. Elwan and A.A. El-Tarabany. 2006. Egyptian Nubian (Zaraibi) crossbred doe goat traits as affected by three gestation patterns (pre-, full- and post-term). Egyptian J Sheep, Goat and Desert Anim. Sci. 1:89-100.

Mukherjee, D. K., S. K. Singh and H. R. Mishra. 1981. Phenotypic correlations of body weight with body measurements in Grey Bengal goats. Indian J. Anim. Sci. 51:682 694.

Mukherjee, D.K., C.S.P. Singh, H.R. Mishra and S. Nath. 1986. Body weight measurement relationships in brown Bengal does. Indian J. Vet. Med. 10 : 1004-1006.

Otoikhian, C.S.O., A. M. Otoikhian, O. P. Akporhuarho and C. Isidahomen. 2008. Correlation of body weight and some body measurement parameters in Ouda sheep under extensive management system. Afr. J. Gen. Agric. 3:129-133.

Salako, A.E. 2006. Application of morphological indices in the assessment of type and function in sheep. Int. J. Morphol. 1:13-18.

Salamena, J. F. and B. J. Papilaja. 2010. Characterization and genetic relationships analysis of buffalo population in Moa Island of South-East West Maluku Regency of Maluku Province. J. Indonesian Trop. Anim. Agric. 2:75 - 82 .
Salamena, J. F., R. R. Noor, C. Sumantri dan I. Inounu. 2007. Hubungan genetic, ukuran populasi efektif dan laju silang dalam per generasi populasi domba di Pulai Kisar. J. Indonesian Trop. Anim. Agric. 2:71-75.

SAS. 2002. SAS/STAT User's Guide Release 9.0 Edition. SAS Institute Inc., Cary. North Carolina.

Shahrbabak, H. M., A. H. K. Farahani, M. M. Shahrbabak and H. M. Yeganeh. 2010. Genetic variations between indigenous fattailed sheep populations. Afr. J. Biotech. 36:5993-5996.

Singh N R., S.C. Mohanty and M. Mishra. 1987. Prediction of body weight from body measurements in Black Bengal goats: a note. Indian J. Anim. Prod. Manag. 3:46-49.

Suparyanto, A., T. Purwadaria and Subandriyo. 1999. Pendugaan jarak genetik dan faktor peubah pembeda bangsa dan kelompok domba di Indonesia melalui pendekatan analisis morfologi. JITV 4:80-87.

Tapio M., M. Ozerov, I. Tapio, M. A. Toro, N. Marzanov, M. Cinkulov, G. Goncharenko, T. Kiselyova, M. Murawski and J. Kantanen. 2010. Microsatellite-based genetic diversity and population structure of domestic sheep in Northern Eurasia. BMC Genetic 11:7686.

Traoré, A., H. H. Tamboura, A. Kabore, L. J. Royo, I. Fernández, I. Álvarez, M. Sangare, D. Bouchel, J. P. Poivey, D. Francois, L. Sawadogo and F. Goyache. 2008. Multivariate analyses on morphological traits of goats in Burkina Faso. Arch. Tierz., Dummerstorf 6:588-600.

Wu, C.H., Y.P. Zhang, S.W.T.D. Bunch and W. Wang. 2003. Mitochondrial control region sequence within the Argali wild sheep (Ovis ammon): Evolution and conservation relevance. Mammalia 1:109-118. 